\title{
A survey of the East Palaearctic Lycosidae (Aranei). 5. Taxonomic notes on the easternmost Palaearctic Pirata species and on the genus Piratosa Roewer, 1960
}

\author{
Обзор восточнопалеарктических Lycosidae (Aranei). \\ 5. Таксономические заметки о наиболее восточном виде \\ рода Pirata и роде Piratosa Roewer, 1960
}

\section{Yuri M. Marusik ${ }^{1}$, Mikhail M. Omelko' \& Seppo Koponen ${ }^{3}$ Ю.М. Марусик ${ }^{1}$, М.М. Омелько ${ }^{2}$, С. Копонен ${ }^{3}$}

\author{
${ }^{1}$ Institute for Biological Problems of the North RAS, Portovaya Str. 18, Magadan 685000 Russia. \\ ИБПС ДВО РАН, Портовая 18, Магадан 685000. \\ ${ }^{2}$ Gornotayozhnaya Station FEB RAS, Gornotayozhnoye Vil., Ussuriyski Dist., Primorski Krai, 692533 Russia. \\ ГТС ДВО РАН, Горнотаёжное, Уссурийский р-н, Приморье 692533. \\ ${ }^{3}$ Zoological Museum, University of Turku, FI-20014 Turku Finland.
}

KEY WORDS: Far East, Siberia, wolf spiders, new synonymy, new combination.

KEY WORDS: Дальний Восток, Сибирь, пауки-волки, новый синоним, новая комбинация.

ABSTRACT. Study of the paratypes of Pirata shibatai Tanaka, 1995 syn.n. from Hokkaido, Japan revealed that it is a junior synonym of $P$. praedo Kulczyński, 1885 described from Kamchatka and known throughout the whole of Siberia and the Russian Far East. Trochosa dybowskii Kulczyński, 1885 syn.n. described and known only from Kamchatka is synonymized with the circum-Holarctic Trochosa terricola Thorell, 1856. The genus Piratosa Roewer, 1960 syn.n. (type species Trochosa dybowskii Kulczyński, 1885) is synonymized with Trochosa C.L. Koch, 1847. Two new combinations are established: Arctosa lawrencei (Roewer, 1960) comb.n. and A. bicoloripes (Roewer, 1960) comb.n. both ex. Piratosa.

РЕЗЮМЕ. Изучение паратипов Pirata shibatai Tanaka, 1995 syn.n. из Хоккайдо показало, что этот вид — младший синоним P. praedo Kulczyński, 1885 описанной из Камчатки и известной по всей Сибири и Дальнему Востоку России. Trochosa dybowskii Kulczyński, 1885 syn.n. описанная из Камчатки синономизирована с циркумголарктическим видом Trochosa terricola Thorell, 1856. Род Piratosa Roewer, 1960 syn.n. (типовой вид Trochosa dybowskii Kulczyński, 1885) синонимизирован с Trochosa C.L. Koch, 1847. Предложены две комбинации: Arctosa lawrencei (Roewer, 1960) comb.n. и A. bicoloripes (Roewer, 1960) comb.n. для видов ранее включавшихся в Piratosa.

\section{Introduction}

In his pioneer work on spiders of Kamchatka, Kulczyński [1885] described 27 species of spiders from the families Araneidae (4), Theridiidae (1), Linyphiidae (11), Gnaphosidae (2), Clubionidae (2), Philodromidae (1), Lycosidae (5) and Salticidae (1).

Among the Lycosidae he described two species of Pirata (P. praedo and P. raptor) and one species of Trochosa (T. dybowskii). Pirata raptor and Trochosa dybowskii were transferred to other genera. The former is now placed in Arctosa C.L. Koch, 1847, and the latter in Piratosa Roewer, 1960 [cf. Platnick, 2009]. T. dybowskii is the type species of the genus Piratosa.

For more than one century, Pirata praedo was known only from Kamchatka, and Piratosa dybowskii remained endemic to the peninsula. In 1992 P. praedo was reported simultaneously from Khabarovsk Province [Logunov, 1992], Yakutia [Koponen \& Marusik, 1992] and Magadan Area [Marusik et al., 1992]. Subsequently, this species was recorded from additional regions of Siberia [Logunov et al., 1998]. Furthermore, it was suggested that $P$. praedo may represent a senior synonym of $P$. shibatai Tanaka, 1995 described from Hokkaido [Marusik et al., 2000]. For a long time we had no possibility to compare the types of both species, but recently we had an opportunity to examine paratype specimens of Pirata shibatai Tanaka, 1995 from Japan and $P$. praedo from several localities in Kamchatka and other parts of the eastern Palaearctic. Examination of this material revealed no differences in the copulatory organs, size, pattern, etc. between the Japanese and Russian specimens and therefore the two names should be synonymized.

Working with East Palaearctic Lycosidae and studying the literature about $P$. praedo we found that the only species of wolf spider from Kamchatka, Piratosa dybowskii, remains poorly known. We believe that both genus and species should be synonymized. 


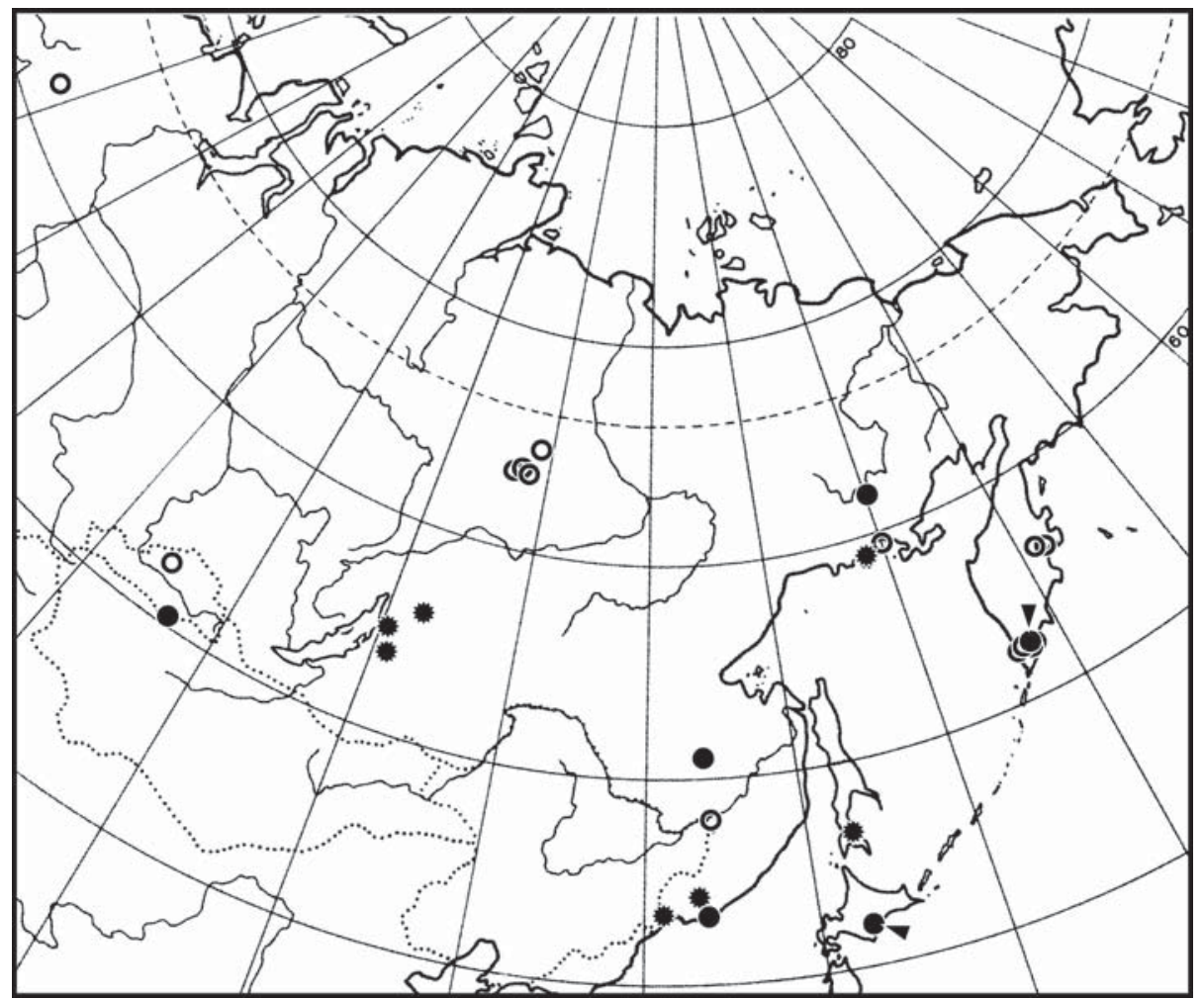

Map 1. Distribution of Pirata praedo: open circles — literature records, star — new records (listed in material), filled circle — studied material.

Карта 1. Распространение Pirata praedo: открытые кружки — литературные данные, звезда — новые точки, залитые кружки — исследованный материал.

In this paper we redescribe Pirata praedo and resolve the uncertainty regarding the genus Piratosa.

\section{Material and methods}

Specimens were photographed using an Olympus Camedia C-5050 camera attached to an Olympus SZX12 stereomicroscope in the Zoological Museum, University of Turku. The images were montaged using «CombineZM» image stacking software. Photographs were taken in dishes of different size with paraffin in the bottom. Different sized holes were made in the bottom to keep the specimens in the correct position. Microphotographs were made with a SEM Jeol JSM-5200 in the Zoological Museum, University of Turku.

The material treated here is shared between the Zoological Museum of the Moscow State University (ZMMU), Zoological Museum, University of Turku (ZMUT) and the Institute for Biological Problems of the North (IBPN).

Abbreviations applied for chaetotaxy: $\mathrm{d}$ - dorsal; $\mathrm{p}$ - prolateral; $\mathrm{r}$ - retrolateral; $\mathrm{v}$ - ventral.

All measurements are given in millimetres.

\section{Pirata praedo}

When Kulczyński described Pirata praedo and $P$. raptor, they were the only records of the genus for the entire Far East. The description of $P$. praedo was based on numerous adult and juvenile specimens from Petropavlovsk-Kamchatski, Kamchatka River and Nachiki Springs. P. praedo was also mentioned in the second publication of Kulczyński [1926] dealing with spiders of Kamchatka. In that paper the species was reported from Javino (=Yavino: W Kamchatka, Apatschinsk Hot Springs; not found on modern maps) and Paratunsky (Paratunskiye Hot Springs). Shortly afterwards, P. praedo was reported and redescribed by Schenkel [1930] on the basis of newly collected specimens from «Paratunka-Tal» (=Paratunskiye Hot Springs). Subsequently, Sytshevskaja [1935] reported this species from additional localities in Kamchatka, namely Kurarotchnoye (=Kurazhye) and Kholmovoye Lakes.

Both Schenkel [1930] and Sytchevskaja [1935] commented on the similarity of Pirata praedo and P. piraticus but regarded the Kamchatkan species as separate. This species was not subsequently treated in literature until 1988 when Yu and Song [1988] synonymized it with $P$. piraticus (Clerck, 1758), but without studying any type specimens. Logunov [1992] published a detailed redescription of $P$. praedo, based on a study of the type material and specimens he collected near Khabarovsk and Tuva, and proved that it is a distinct species, which is most similar to P. tenuitarsis Simon, 1876 rather than to $P$. piraticus. In the same work, Logunov selected lectotype male from Nachiki Springs. 

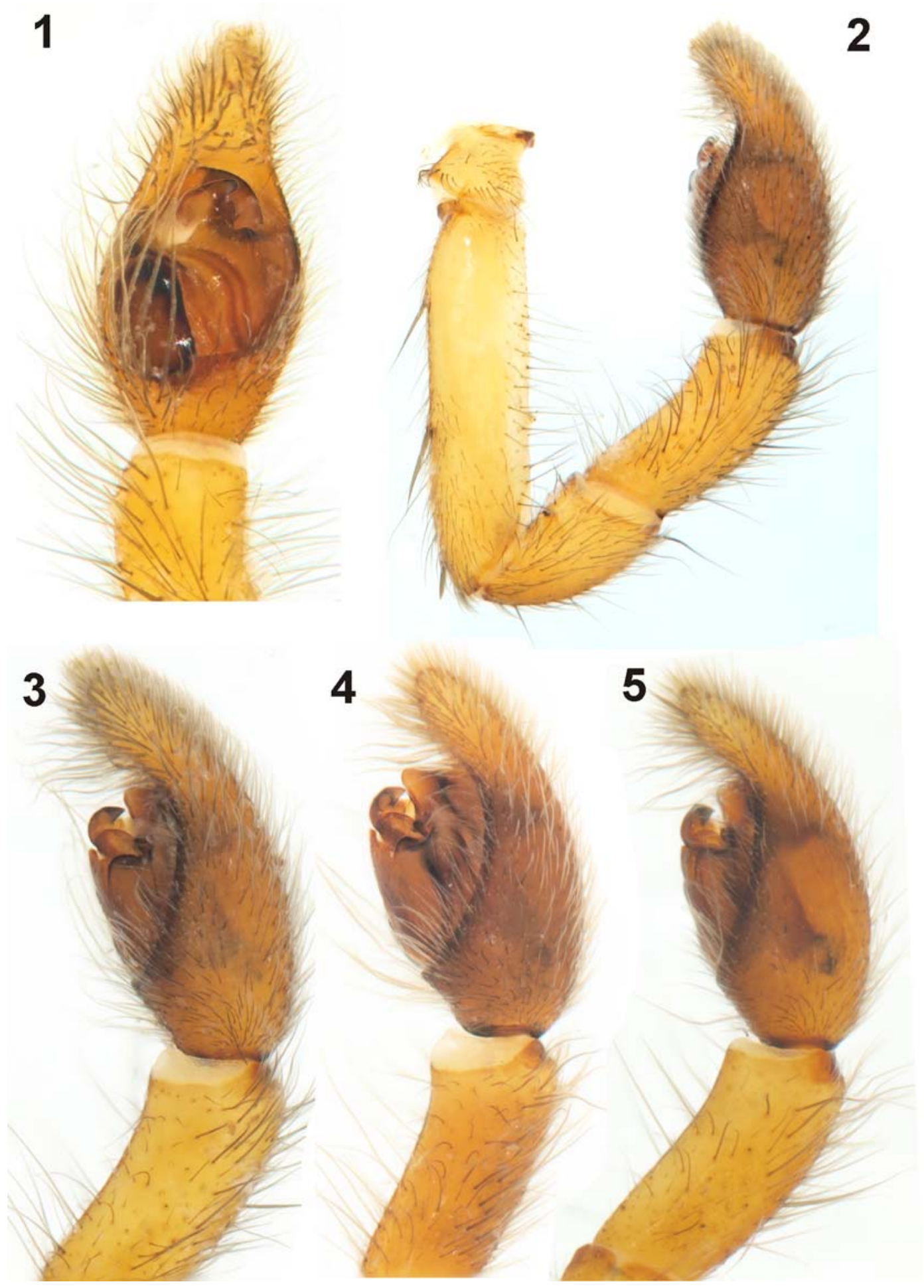

Figs 1-5. Male palp of Pirata praedo: 1 - ventral; 2-5 - retrolateral. 1-3 - from Kamchatka. 4 - paratype of P. shibatai. 5 from Maritime Province.

Рис. 1-5. Пальпа самца Pirata praedo: 1 - вентрально; 2-5 — ретролатерально. 1-3 - с Камчатки. 4 — паратип P. shibatai. 5 - из Приморья. 


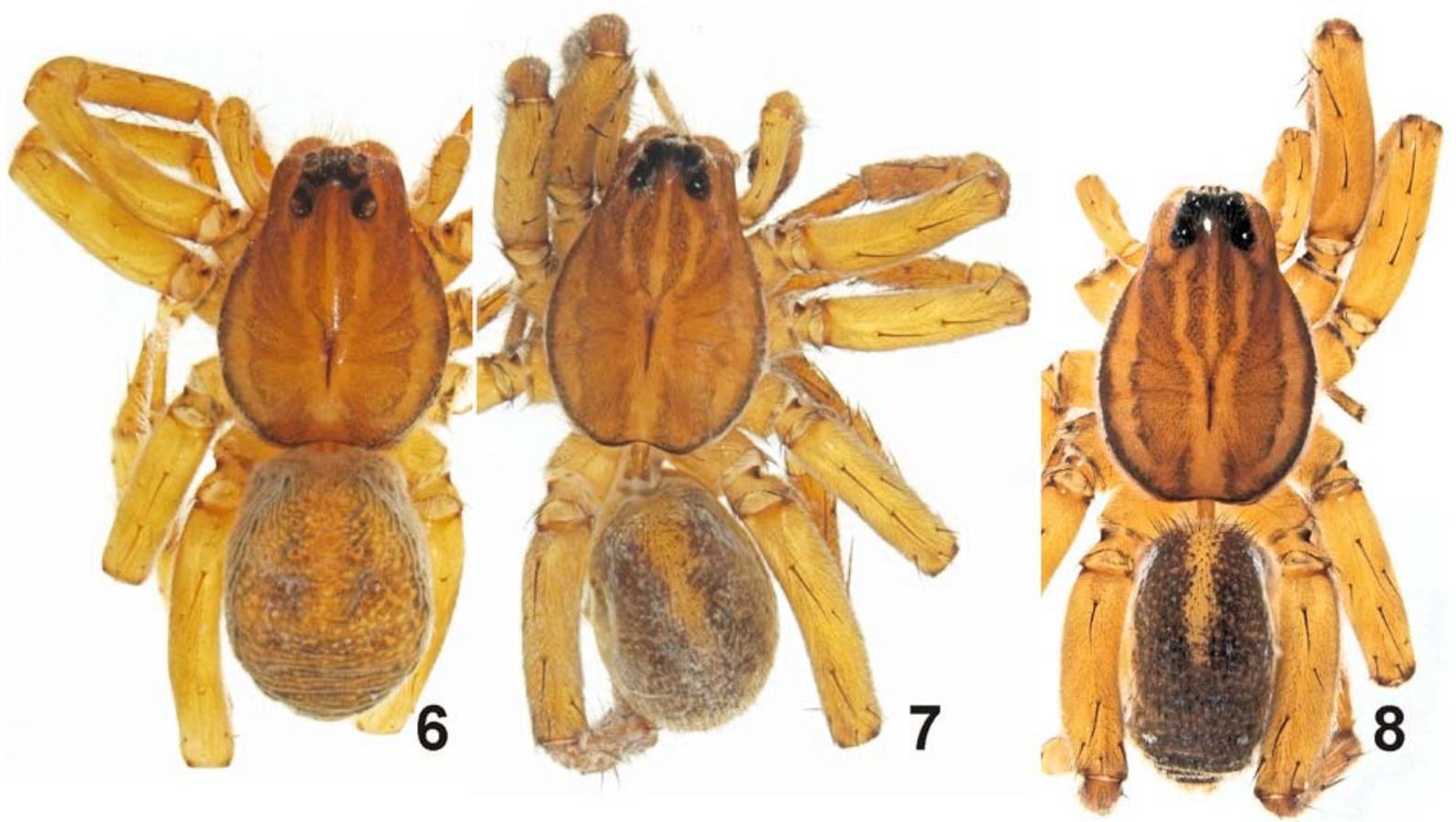

Figs 6-8. Habitus of Pirata praedo: 6, 8- male; 7 - female. 6-7 - from Kamchatka. 8 - from Maritime Province.

Рис. 6-8. Habitus of Pirata praedo: 6, 8 - самец; 7 - самка. 6-7 - с Камчатки. 8 - из Приморья.
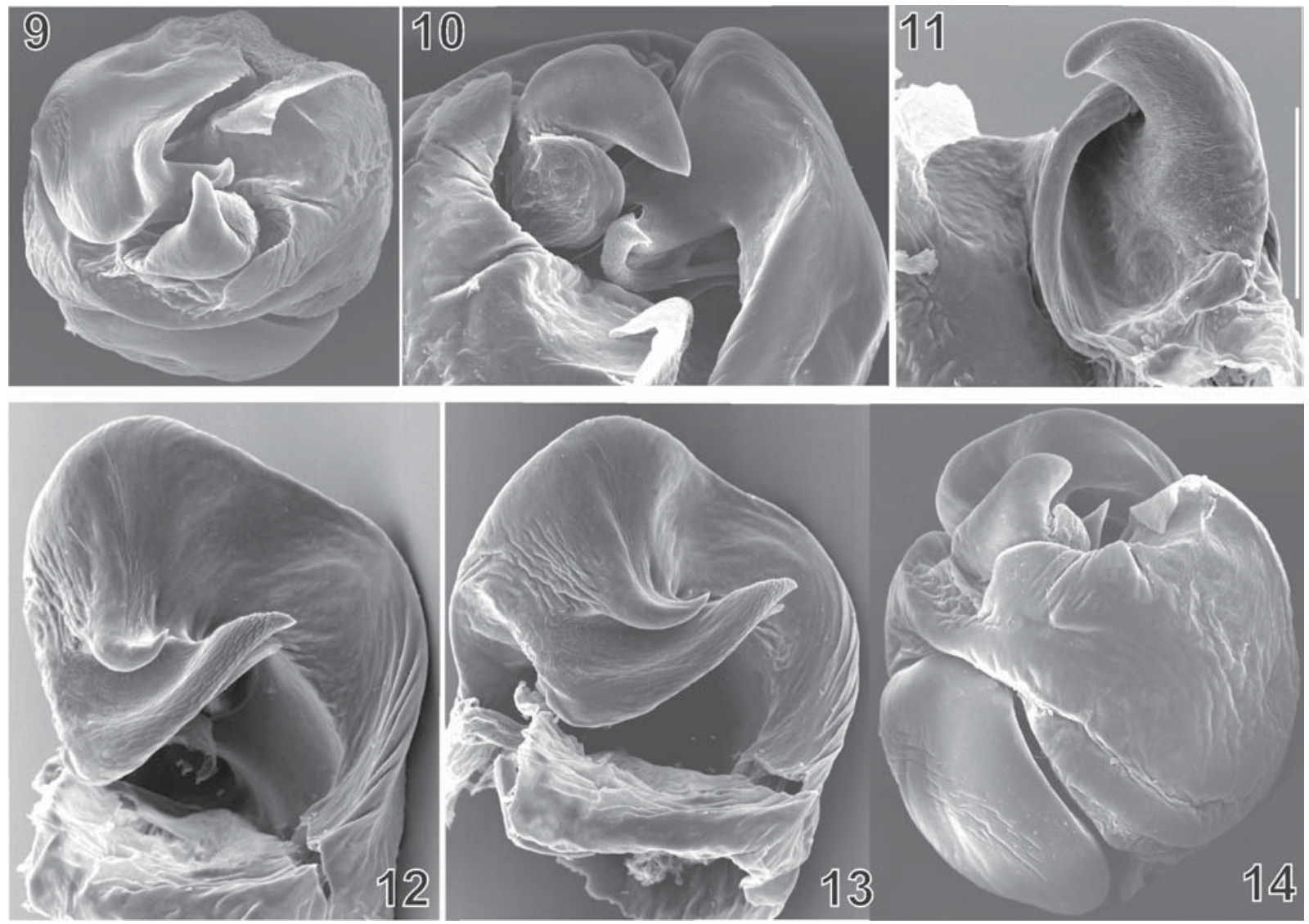

Figs 9-14. Bulbus of Pirata praedo from Maritime Province: 9 - from above; 10 - from above-retrolateral; 11 - tegular apophysis, dorsal; 12 - embolic division, retrolateral; 13 - embolic division, ventral; 14 - bulbus, ventral.

Рис. 9-14. Бульбус Pirata praedo из Приморья: 9 - сверху; 10 - сверху-ретролатерально; 11 - тегулярный отросток, сверху; 12 - эмболюсный отдел, ретролатерально; 13 - эмболюсный отдел, снизу; 14 - бульбус, вентрально. 

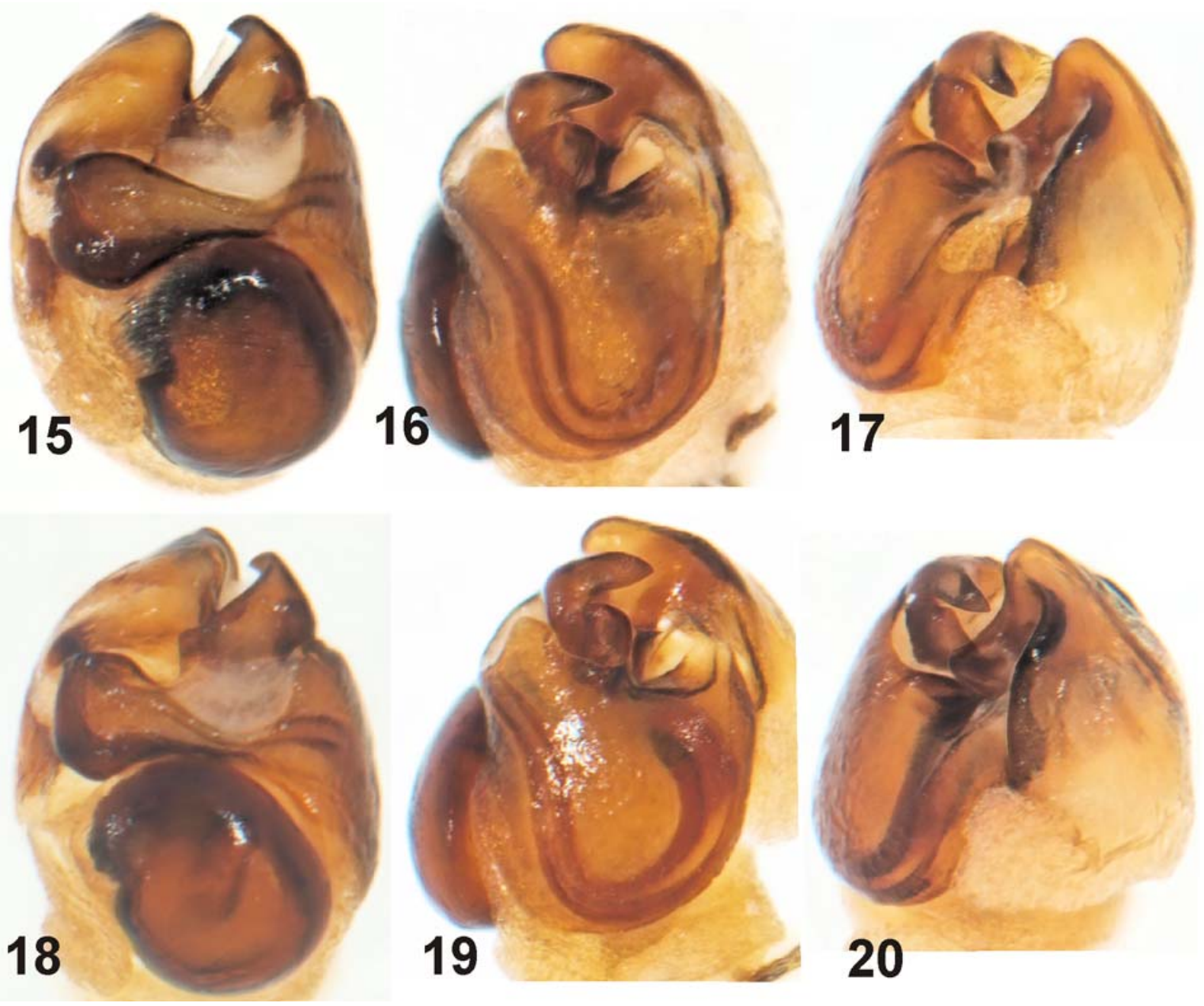

Figs 15-20. Bulbus of Pirata praedo from Kamchatka (15-17) and Japan (18-20, paratype of P. shibatai): 15, 18 - prolateral view; 16, 19 - retrolateral-ventral view; 17, 20 - prolateral-from above.

Рис. 15-20. Бульбус Pirata praedo с Камчатки (15-17) и из Японии (18-20, паратип P. shibatai): 15, 18 — пролатериально; 16, 19 - ретролатерально-вентрально; 17, 20 - пролатерально-сверху.

Logunov's paper was the first to indicate the occurrence of $P$. praedo outside of the Kamchatka Peninsula. At the same time Marusik et al. [1992] reported this species from the upper reaches of the Kolyma River $\left(\right.$ ca $62^{\circ} \mathrm{N}$ ) and Koponen \& Marusik [1992] mentioned it from one locality in Yakutia. In the following year $P$. praedo was reported from several localities in Central Yakutia [Marusik et al., 1993]. P. praedo was also treated in a check-list of Tuvan spiders [Logunov et al., 1998] and in a survey of spiders from Tuva [Marusik et al., 2000]. The latter publication included a distribution map for this species and indicated that $P$. shibatai Tanaka, 1995 described from Hokkaido could be conspecific. Very recently, P. praedo was reported from the Maritime Province [Omelko, 2006] and the North Urals [Esyunin \& Kazantsev, 2007]. These records extended the known range approximately $5^{\circ}$ to the south (in the continental part of Asia) and $35^{\circ}$ to the West.

\section{Pirata praedo Kulczyński, 1885}

Figs 1-29.

P. p. Kulczyński, 1885: 56, pl. 11, f. 34 (D ${ }^{7}+$ ).

P. p.: Schenkel. 1930: 31, f. 12a,b $\left(\sigma^{\top}+\right)$, reference not mentioned in Platnick [2009].

Piratula p.: Roewer, 1955: 288.

P. piraticus: Yu \& Song, 1988: 119, synonymized $P$. praedo.

$P$. p. Logunov, 1992: 60, f. 6a- $\Gamma\left(\sigma^{\top}+\right)$, removed from synonymy of $P$. piraticus.

P. shibatai Tanaka, 1995: 47, f. 1-4 (D ${ }^{7}+$ ). Syn.n.

FAUNISTIC RECORDS. Kulczyński, 1926; Sytshevskaya, 1935; Koponen \& Marusik, 1992; Logunov, 1992; Marusik et al., 1992, 1993; Logunov et al., 1998; Marusik et al., 2000; Marusik, 2005a,b; Omelko, 2006; Esyunin \& Kazantsev, 2007.

MATERIAL EXAMINED. RUSSIA: Tuva: $6 \sigma^{7} \sigma^{\top} 5$ oq (ZMMU), Tere-Khol' Lake, Sharlaa Stand, 5001.47'N 9503.45'E, 1050 m, 6-14.07.1996 (Y.M. Marusik). Buryatia: $1 \sigma^{7}$ (ZMUT), Vitim River, Bargalino, bog, 5.08.1976 (E. Alekseeva); $2 \bigcirc^{\top} \sigma^{\top} 1$, 

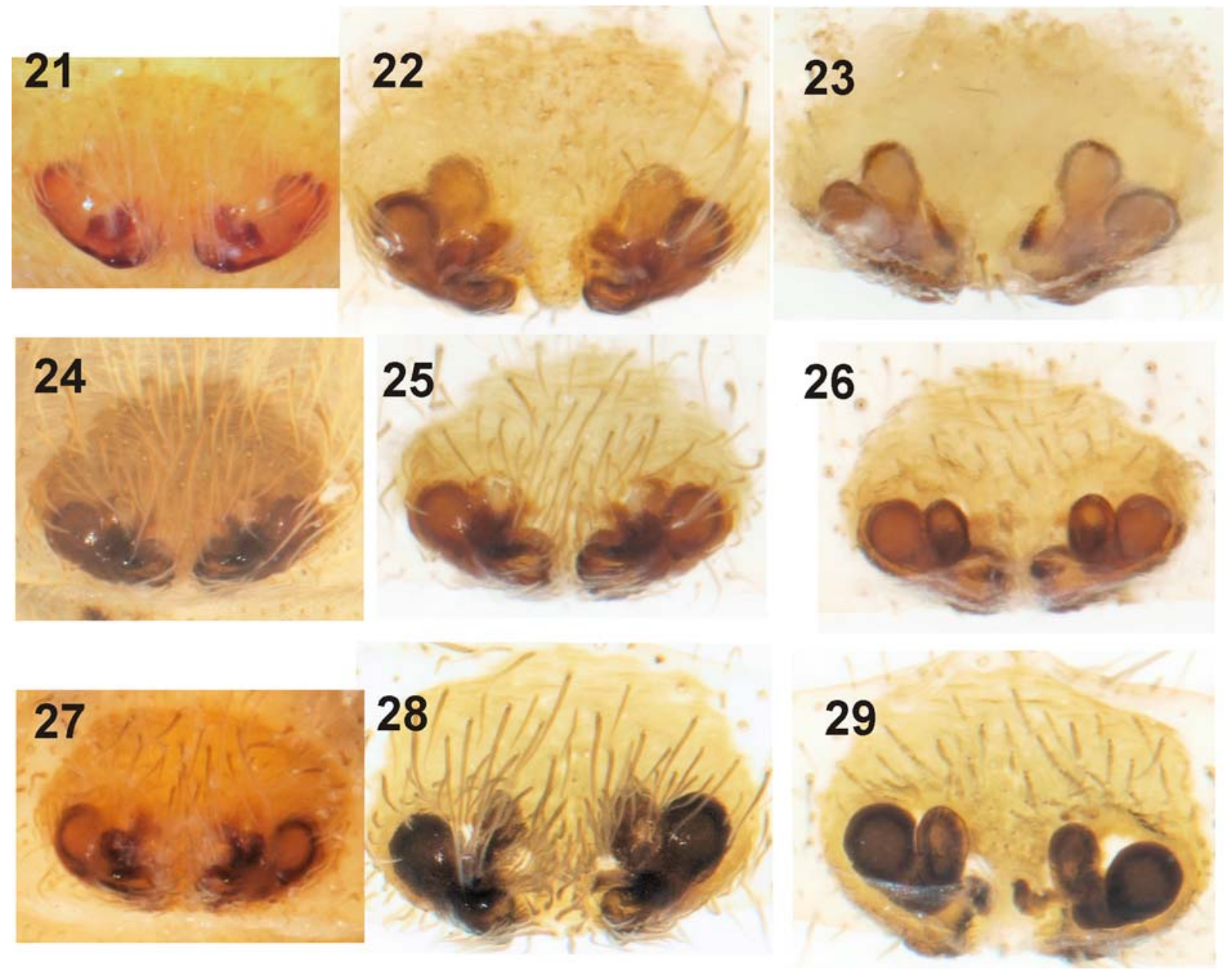

Figs 21-29. Epigyne of Pirata praedo from Kamchatka (21-23), Japan (24-26, paratype of P. shibatai) and Maritime Province (2728): 21-22, 24-25, 27-28 - ventral view; 23, 26, 29 - dorsal view. 22-23, 25-26, 28-29 - dissected epigynes, after maceration.

Рис. 21-29. Эпигина Pirata praedo с Камчатки (21-23), Японии (24-26, паратип P. shibatai) и Приморья (27-28): 21-22, 2425, 27-28 - вентрально; 23, 26, 29 - сверху. 22-23, 25-26, 28-29 - отпрепарированная эпигина после мацерации.

(ZMMU), Ugnasai, 7.06.1995 (S. Danilov); 1 OT 2 우 (ZMUT), Barguzin Valley, Seya Hot Springs, $54^{\circ} 50^{\prime} \mathrm{N} 11^{\circ} 18^{\prime} \mathrm{E}, 600 \mathrm{~m}$, 3.07.1996 (M. Uusitalo). Khabarovsk Prov.: $20^{7} 0^{7} 1$ ( 1 (ZMMU), Bureya River upper reaches, Umalta River, ox-bow in Chosenia forest, 2.06.2001 (L. Trilikauskas). Magadan Area: $50^{7} \sigma^{7} 5$ 우오 (IBPN) Kolyma River upper reaches, ca $62^{\circ} \mathrm{N}$, Aborigen Field Station, bog near Kolyma River, Summer 1983 (Yu.M. Marusik); $3 \mathrm{O}^{7} \mathrm{O}^{7}$ (IBPN), Chelomdzha River, Field Station, Summer 1987 (N.E. Dokuchaev). Kamchatka: 1 ㅇ (ZMMU Ta-2455), Kamchatka River, $2.5 \mathrm{~km}$ downstream of Krasnaya Vil., 19.08.1930 (Sytchevskaya); 1 ( (ZMMU), near Khomnovoye Vil., Kamchatka River, on moist soil, 07.1930 (Sytchevskaya); 6 우 (ZMMU Ta-2458), near Khomnovoye Vil., Kamchatka River, on moist soil, 16.08.1930 (Sytchevskaya); 1 + 4juv. (ZMMU Ta-2461), Kamchatka River, near Yelovka River, 30.08.1930 (Sytchevskaya); $4 \mathrm{O}^{7} \mathrm{O}^{7} 2$ 우 (IBPN), 10-12 km N of Paratunka Vill., Yelizovo Forestry, $53.050^{\circ} \mathrm{N} 158.225^{\circ} \mathrm{E}, 15-28.07 .2004$ (A.S.Ryabukin). Maritime Prov.: $4 \bigcirc^{7} \sigma^{7} 2$ 우 (ZMMU), Lazo Reserve, Proselochnaya bay, 8-12.04.2006 (Yu. Sundukov); 2 ○ $0^{7} 1$ क (ZMMU) Lazo Dist., Chukhunenko Lake, 19-25.07.2005 (M.M. Omelko); 2 O $^{7} 3$ 우우 (ZMMU), Khasan Dist., Lotos lake, 17-18.07.2004 (M.M. Omelko). Sakhalin Isl.: $1 O^{7}$ (IBPN), SE part of Sakhalin, env. of Starodubskoye Vil., Naiba River mouth part, $47^{\circ} 24.992^{\prime} \mathrm{N}$ $142^{\circ} 45.384^{\prime}$ E, 23.07.2001 (Yu.M. Marusik). JAPAN: Hokkaido: Paratypes of $P$. shibatai, $1 \sigma^{\top} 2$ † (ZMMU), Toyokoro-cho, Ohtsu-shitchi, 27.06.1993 (K. Shibata).
DESCRIPTION. Male. Total length 6.05-6.70. Carapace: 2.90-3.40 long, 2.10-2.55 wide. Carapace/femur I length ratio 1.29-1.36. Carapace light brown with dark brown marginal stripes, pair of submedian wide bands, and thin parallel stripes in thoracic part merging near median grove. Submedian dark band wider than median light band, and twice as wide as the light submarginal light bands. Abdomen with more or less distinct lightbrown heart mark. White spots absent.

Palp as in Figs 1-20. Femur as long as patella and tibia; tibia longer than wide, length/width ratio 2.4; cymbium approximately 1.33 times longer than tibia; subtegulum large, its height is greater than? of the bulbal height; median (=tegular) apophysis small, as wide as tall, its height is two times shorter than those of the subtegulum. Chaetotaxy of $\sigma^{7}$ :

\begin{tabular}{|l|l|l|l|c|}
\hline & \multicolumn{1}{|c|}{ Femur } & Patella & \multicolumn{1}{c|}{ Tibia } & Metatarsus \\
\hline I & $3 \mathrm{~d}, 1 \mathrm{p}(2 \mathrm{p}), 1 \mathrm{r}$ & $1 \mathrm{p}(1 \mathrm{r})$ & $2 \mathrm{p}, 2 \mathrm{r}, 2-2 \mathrm{v}$ & $2 \mathrm{p}, 1 \mathrm{r}, 2-2 \mathrm{v}$ \\
\hline II & $3 \mathrm{~d}, 2 \mathrm{p}, 2 \mathrm{r}(1 \mathrm{r})$ & $1 \mathrm{p}$ & $2 \mathrm{p}, 2 \mathrm{r}, 2-2 \mathrm{v}$ & $2 \mathrm{p}, 2 \mathrm{r}, 2-2 \mathrm{v}$ \\
\hline III & $3 \mathrm{~d}, 2 \mathrm{p}, 2 \mathrm{r}(1 \mathrm{r})$ & $1 \mathrm{p}, 1 \mathrm{r}$ & $2 \mathrm{~d}, 2 \mathrm{p}, 2 \mathrm{r}, 2-2 \mathrm{v}$ & $2 \mathrm{p}, 2 \mathrm{r}, 2-2 \mathrm{v}$ \\
\hline IV & $3 \mathrm{~d}, 2 \mathrm{p}, 1 \mathrm{r}$ & $1 \mathrm{p}, 1 \mathrm{r}$ & $2 \mathrm{~d}, 2 \mathrm{p}, 2 \mathrm{r}, 2-2 \mathrm{v}$ & $2 \mathrm{p}, 2 \mathrm{r}, 2-2 \mathrm{v}$ \\
\hline
\end{tabular}


Female. Total length 6.7-9.1. Carapace: 3.45-3.75 long, 2.5-2.90 wide. Carapace/femur I length ratio 1.291.5. Coloration as in male. Epigyne as in Figs 21-29, without septum or fovea, but with only translucent receptacula.

Chaetotaxy of + .

\begin{tabular}{|l|l|l|l|l|}
\hline & \multicolumn{1}{|c|}{ Femur } & \multicolumn{1}{|c|}{ Patella } & \multicolumn{1}{c|}{ Tibia } & \multicolumn{1}{c|}{ Metatarsus } \\
\hline I & $3 \mathrm{~d}, 1 \mathrm{p}$ & & $2-2 \mathrm{v}$ & $2-2 \mathrm{v}$ \\
\hline II & $3 \mathrm{~d}, 2 \mathrm{p}$ & $1 \mathrm{p}$ & $2 \mathrm{p}, 2-2 \mathrm{v}$ & $1 \mathrm{p}, 2-2 \mathrm{v}$ \\
\hline III & $3 \mathrm{~d}, 2 \mathrm{p}, 2 \mathrm{r}$ & $1 \mathrm{p}, 1 \mathrm{r}$ & $2 \mathrm{~d}, 2 \mathrm{p}, 2 \mathrm{r}, 2-0 \mathrm{v}$ & $2 \mathrm{p}, 2 \mathrm{r}, 2-2 \mathrm{v}$ \\
\hline IV & $3 \mathrm{~d}, 2 \mathrm{p}, 1 \mathrm{r}$ & $1 \mathrm{p}, 1 \mathrm{r}$ & $2 \mathrm{~d}, 2 \mathrm{p}, 2 \mathrm{r}, 2-1 \mathrm{v}$ & $2 \mathrm{p}, 2 \mathrm{r}, 2-2 \mathrm{v}$ \\
\hline
\end{tabular}

COMMENTS. We originally studied $P$. praedo from different populations with the assumption that they represented several sibling species. Therefore, we tried to find differences between specimens from distant populations, but were unable to do so. All the specimens were the same with regard to pattern, colouration, body size, size and shape of copulatory organs. Similarly, no differences were found between the paratypes of $P$. shibatai and the Kamchatkan specimens and therefore two names are synonymized here.

HABITAT. This species has been collected only from bogs. All the bogs where this species was found in Magadan Area, Tuva, Buryatia, Sakhalin and Kamchatka were located close to rivers or lakes. In the continental regions of Siberia (Yakutia, Kolyma, Buryatia, Khabarovsk) it can apparently survive in permafrost-free habitats, such as river valleys and large lakes.

DISTRIBUTION. P. praedo has an East Palaearctic boreo-nemoral distribution and is known from Ural to Kamchatka, south to Tuva, Maritime Province and Hokkaido. Although it occurs in the nemoral zone, it inhabits only boreal habitats.

The genus Piratosa

\section{Trochosa terricola Thorell, 1856} Syn.n.

Trochosa dybowskii Kulczyński, 1885: 54, pl. 11, f. 32 (DOT).

Piratessa dybwoskii: Roewer, 1955: 286.

Piratosa dybwoskii: Roewer, 1960: 913 (selected species as the generotype).

T. t. Fuhn \& Niculescu-Burlacu, 1971: 231, f. 113a-e ( $0^{7}+$ ).

T. t. Tanaka, $1988 \mathrm{c}: 95$, f. 1-4 ( (

T. t. Chikuni, 1989b: 108, f. 2 ( (

T. t. Dondale \& Redner, 1990: 23, f. 5-8 ( ( $^{7}+$ ).

MATERIAL EXAMINED. 2 우 from Kamchatka, Paratunka, 2004 (A.S. Ryabukhin) and numerous $\sigma^{7} \sigma^{7}$ and $O 9$ from Kuril Islands and $2 O^{7} \sigma^{\top} 2$ 우 from the environs of Magadan.

COMMENTS. The original description of Trochosa dybowskii includes a clear statement to the effect that the Kamchatkan species is related to European Trochosa spp. (robusta, ruricola, terricola). Judging from the figures and description provided by Kulczyński [1885] and recent distribution data for T. terricola, the single species of Trochosa in the adjacent areas studied (all Kuril Islands, Magadan, vicinity of Petropavlovsk) it is safe to conclude that the name T. dybowskil should be synonymized with $T$. terricola.

Roewer [1960] selected Trochosa dybowskii as the type species for his new genus Piratosa. Besides $T$. dybowskii (known by males from Kamchatka) he included two new species in this genus: $P$. bicoloripes Roewer, 1960 and P. lawrencei Roewer, 1960 from Rwanda and Cape Province of South Africa respectively. Both species were described and are still known only from female specimens. It is unclear why he placed these species in the same genus, given that they are known from different sexes and distant locations. It is worth mentioning that Roewer had not examined the types of Trochosa dybowskii. Because the type species of Piratosa Roewer, 1960 was synonymized here with Trochosa terricola, the two generic names must also be synonymized Piratosa Roewer, 1960 syn.n. = Trochosa C.L. Koch, 1847. We are not sure in what genus the two remaining species should be placed, but judging from the description and figures provided by Roewer [1960] they are not related to Trochosa. The epigyne of Piratosa lawrencei Roewer, 1960 is similar to the epigyne of Arctosa maculata (Hahn, 1822). Because of these similarities we tentatively transfer both species from Piratosa to Arctosa: Arctosa lawrencei (Roewer, 1960) comb.n. and A. bicoloripes (Roewer, 1960) comb.n.

ACKNOWLEDGEMENTS. We thank Hozumi Tanaka, Alexander S. Ryabukhin, Dmitry V. Logunov, Laimonas Trilikauskas and Yury N. Sundukov who supplied us with comparative material. Dave Penney (Manchester, UK) is thanked for his kind help in editing the English of the final draft. This project was supported in part by the Russian Foundation for Basic Research grants \#\# 08-04-92230 and 09-04-01365.

\section{References}

Chikuni Y. 1989. Pictorial Encyclopedia of Spiders in Japan. Kaisei-sha Publ. Co. Tokyo. 310 pp.

Dondale C.D., Redner J.H. 1990. The insects and arachnids of Canada, Part 17. The wolf spiders, nurseryweb spiders, and lynx spiders of Canada and Alaska, Araneae: Lycosidae, Pisauridae, and Oxyopidae. Research Branch, Agriculture Canada. No.1856. 383 pp.

Esyunin S.L., Kazantsev D.K. 2008. On the spider (Aranei) fauna of the Pechoro-Ilychskiy Reserve (north Urals), with the description of a new Agroeca species (Liocranidae) // Arthropoda Selecta. Vol.16 (for 2007). No.4. P.245-250.

Fuhn I.E., Niculescu-Burlacu F. 1971. Fam. Lycosidae // Fauna Republicii Socialiste Romania (Arachnida). Bucuresti. Vol.5. No.3. 253 pp.

Koponen S., Marusik Yu.M. 1992. Spiders (Araneae) from Central Yakutia, Siberia // Entomol. Fennica. No.3. P.163-166.

Kulczyński W. 1885. Araneae in Camtschadalia a Dre B. Dybowski collectae // Pam. Wydz. matem.-przyz. Akad. Umiej. Krakow. T.11. P.1-60.

Kulczyński W. 1926. Arachnoidea Camtschadalica // Annu. Zool. Mus. AN URSS. Vol.27. No.1. P.29-72.

Logunov D.V. 1992. [To the spider fauna of the Bolshekhekhtsyrski State Reserve (Khabarovsk Province). I. Families Araneidae, Lycosidae, Philodromidae, Tetragnathidae and Thomisidae] // Sib. Biol. Zhurn. Vyp.4. P.56-68 [in Russian].

Logunov D.V., Marusik Yu.M., Koponen S. 1998. A check-list of the spiders in Tuva, South Siberia with analysis of their habitat distribution // Ber. nat.-med. Verein Innsbruck. Vol.85. P.125159. 
Marusik Yu.M. 2005. [Arachnids (Arachnida: Aranei, Opiliones) of northern Cisokhotia] // Euroasian Entomol. J. Vol.4. No.3. P.187-208 [in Russian].

Marusik Yu.M. 2005. [Spiders and harvestmen of the Taui Bay shore and adjacent parts of northern Cisokhotia] // Biodiversity of Tauysk Bay of the Sea of Okhotsk. P.262-289 [in Russian].

Marusik Yu.M., Eskov K.Yu., Kim J.P. 1992. A check-list of spiders (Aranei) of Northeast Asia // Korean Arachnol. Vol.8. No.1-2. P.129-158.

Marusik Yu.M., Eskov K.Yu., Koponen S., Vinokurov N.N. 1993. A check-list of the spiders (Aranei) of Yakutia, Siberia // Arthropoda Selecta. Vol.2. No.2. P.63-79.

Marusik Yu.M., Logunov D.V., Koponen S. 2000. Spiders of Tuva, South Siberia. Magadan: IBPN FEB RAS. 252 pp.

Omelko M.M. 2006. [Biological and faunistic survey of the wolf spiders (Aranei, Lycosidae) from the environs of marine field station «Zapovednoye» (South Primorye)] // Chteniya pamyat A.I. Kurentsova. Vladivostok: Dalnauka. Vyp.17. P.128-133 [in Russian].
Platnick N.I. 2009. The world spider catalog, version 9.5. American Museum of Natural History, online at http://research.amnh. org/entomology/spiders/catalog/index.html

Roewer C.F. 1955. Katalog der Araneen von 1758 bis 1940, bzw. 1954. Bruxelles. Bd.2. $1751 \mathrm{~S}$.

Roewer C.F. 1960. Araneae Lycosaeformia II (Lycosidae) (Fortsetzung und Schluss) // Explor. Parc natn. Upemba Miss. G. F. de Witte. T.55. P.519-1040.

Schenkel E. 1930. Die Araneiden der schwedischen KamtchatkaExpedition 1920-1922 // Ark. Zool. Bd.21A. Nr.15. S.1-33.

Sytshevskaya V.J. 1935. Étude sur les araignées de la Kamtchatka // Folia zool. hydrobiol. Vol.8. No.1. P.80-103.

Tanaka H. 1988. Lycosid spiders of Japan II. The genus Trochosa C. L. Koch. // Acta arachnol. Vol.36. No.1. P.93-113.

Tanaka H. 1995. A new species of the genus Pirata Sundevall (Araneae: Lycosidae) from Japan // Acta arachnol. Vol.44. No.1. P.47-49

Yu L.M., Song D.X. 1988. A revision of the Chinese spiders of the family Lycosidae (Araneae) // Sinozool. Vol.6. P.113-121. 